\title{
Evaluating methods for estimating whole house air infiltration rates in summer: implications for overheating and indoor air quality
}

Estimating infiltration rates in summer

\author{
Ben M. Roberts, David Allinson and Kevin J. Lomas \\ Building Energy Research Group, School of Architecture, \\ Building and Civil Engineering, Loughborough University, Loughborough, UK
}

\begin{abstract}
Purpose - Accurate values for infiltration rate are important to reliably estimate heat losses from buildings. Infiltration rate is rarely measured directly, and instead is usually estimated using algorithms or data from fan pressurisation tests. However, there is growing evidence that the commonly used methods for estimating infiltration rate are inaccurate in UK dwellings. Furthermore, most prior research was conducted during the winter season or relies on single measurements in each dwelling. Infiltration rates also affect the likelihood and severity of summertime overheating. The purpose of this work is to measure infiltration rates in summer, to compare this to different infiltration estimation methods, and to quantify the differences.

Design/methodology/approach - Fifteen whole house tracer gas tests were undertaken in the same test house during spring and summer to measure the whole building infiltration rate. Eleven infiltration estimation methods were used to predict infiltration rate, and these were compared to the measured values. Most, but not all, infiltration estimation methods relied on data from fan pressurisation (blower door) tests. A further four tracer gas tests were also done with trickle vents open to allow for comment on indoor air quality, but not compared to infiltration estimation methods.

Findings - The eleven estimation methods predicted infiltration rates between 64 and $208 \%$ higher than measured. The ASHRAE Enhanced derived infiltration rate $(0.41 \mathrm{ach})$ was closest to the measured value of 0.25 ach, but still significantly different. The infiltration rate predicted by the "divide-by-20" rule of thumb, which is commonly used in the UK, was second furthest from the measured value at $0.73 \mathrm{ach}$. Indoor air quality is likely to be unsatisfactory in summer when windows are closed, even if trickle vents are open.

Practical implications - The findings have implications for those using dynamic thermal modelling to predict summertime overheating who, in the absence of a directly measured value for infiltration rate (i.e. by tracer gas), currently commonly use infiltration estimation methods such as the "divide-by-20" rule. Therefore, infiltration may be overestimated resulting in overheating risk and indoor air quality being incorrectly predicted.

Originality/value - Direct measurement of air infiltration rate is rare, especially multiple tests in a single home. Past measurements have invariably focused on the winter heating season. This work is original in that the tracer gas technique used to measure infiltration rate many times in a single dwelling during the summer.
\end{abstract}

(C) Ben M. Roberts, David Allinson and Kevin J. Lomas. Published by Emerald Publishing Limited. This article is published under the Creative Commons Attribution (CC BY 4.0) licence. Anyone may reproduce, distribute, translate and create derivative works of this article (for both commercial and noncommercial purposes), subject to full attribution to the original publication and authors. The full terms of this licence may be seen at $\mathrm{http} / / /$ creativecommons.org/licences/by/4.0/legalcode.

The authors wish to thank technical staff in the School of Architecture, Building and Civil Engineering at Loughborough University: Mark Harrod for ensuring health and safety requirements were met during tracer gas tests; Mick Barker for the delivery of numerous canisters of $\mathrm{CO}_{2}$ to the test houses and ensuring the regulator was connected safely; and Dean Sanham who maintained the School weather station. The authors acknowledge Loughborough University's continued provision of 24-h security and ongoing maintenance of the test houses.

Funding: This work was funded by the London-Loughborough Centre for Doctoral Research in Energy Demand (grant EP/L01517X/1).

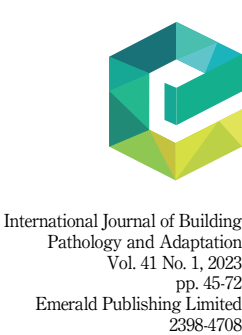

DOI 10.1108/IJBPA-06-2021-0085 
IJBPA

41,1
This work is also original in that it quantifies both the infiltration rate and its variability, and compares these to values produced by eleven infiltration estimation methods.

Keywords Energy efficiency, Indoor air quality, IAQ, Overheating, Infiltration, Building fabric, Test houses, Dwellings, Measurement, Tracer gas, Fan pressurisation, Blower door

Paper type Research paper

\section{Introduction}

Air infiltration (and exfiltration), i.e. the air which moves in (and out) of a building through adventitious openings in the envelope, and the rate at which it occurs is important for the accurate prediction of heat losses from buildings and assessment of indoor air quality. Knowing how much heat a building loses (or gains) via infiltration has implications for both wintertime heating demand and summertime overheating.

Globally, heat demand [1] accounts for more than half of final energy consumption and around $12 \mathrm{GtCO}_{2}$ or $40 \%$ of global annual energy related emissions in 2014 (Collier, 2018). In the UK, and most other countries, heat is invariably produced by the combustion of fossil fuels. Thus, heat accounts for around a third of UK greenhouse gas (GHG) emissions with around $50 \%$ of heat-related emissions coming from the domestic sector (HMG, 2016). However, because of the warming climate, space cooling is fast-growing in buildings, although it still only accounts for around $2 \%$ of global energy consumption (Collier, 2018). Even in temperate climates, an increase in domestic air conditioning is anticipated, although estimates of the likely uptake vary widely, e.g. from $5 \%$ to $32 \%$ of UK homes by 2050 (Crawley et al.,2020b). The efficiency with which homes can be cooled is highly dependent on the fabric energy efficiency and thus the infiltration rate. An understanding of, and means of measuring and estimating, the air movement through a building's fabric is therefore an important component of any greenhouse gas reduction policy.

Whether dwellings are being heated or cooled, maintaining indoor air quality is essential to the health of the occupants. In the UK, trickle vents, usually located in the window system, are the preferred means of passive background ventilation (HM Government, 2010). Uncontrolled air leakage, i.e. infiltration, through the building envelope adds to this purposeful ventilation. However, unless infiltration rates are measured or estimated reliably, occupants are at risk of exposure to poor indoor air quality.

There are two established methods for determining infiltration rates in dwellings (Warren and Webb, 1980a). Infiltration can be measured directly, most commonly using a tracer gas technique, or the air permeability of the building's thermal envelope can be measured by, most commonly, fan pressurisation (blower door test) and then used to estimate the infiltration rate using a model. Thus, tracer gas is the preferred method of measuring infiltration rate if accuracy is the only consideration.

However, tracer gas tests require expensive equipment and care must be taken to ensure the tracer gas is properly mixed with the dwelling air, usually via multiple fans. This, along with the release of potentially dangerous gases, means that tracer gas tests are often impractical in occupied homes. In contrast, a fan pressurisation (blower door) test can be performed relatively quickly, i.e. 30 min including set up time, with intrusion on the occupant limited to that time period only. Therefore, doing a fan pressurisation test is usually preferable to a tracer gas test.

Due to the relative speed and convenience of a fan pressurisation test, they are completed in far greater volumes than tracer gas tests, as evidenced in numerous international studies (e.g. Sfakianaki et al, 2008; Pan, 2010; Alfano et al., 2012; Sinnott and Dyer, 2012; Ramos et al., 2015; Vinha et al., 2015; Fernández-Agüera et al., 2016; Ji and Duanmu, 2017; Ashdown et al., 2020; Mélois et al, 2019). In the UK it is estimated that 73\% of all newly built dwellings have had a fan pressurisation test done (Love et al., 2017), amounting to approximately 130,000 
results lodged with the Air Tightness Testing and Measurement Association (ATTMA) database annually (Crawley et al., 2020a). Similarly, in the USA there are over 70,000 recorded results (Chan et al.,2005). Due to the wealth of fan pressurisation data and comparative lack of tracer gas data, building designers and dynamic thermal modellers usually rely on infiltration rates that are derived from fan pressurisation data.

Despite the relative ease and minimal intrusion of a fan pressurisation test, the key downside is that infiltration rate is not measured directly. This is because the blower door fan induces an elevated pressure difference across the building envelope, which is intended to remove the effect of variable weather conditions (Chan et al., 2013). Whilst useful for building quality control, fan pressurisation can only measure the dwelling envelope air permeability, i.e. a property of the building fabric which relates to infiltration (Sherman and Dickerhoff, 1998), but not the infiltration rate itself. Infiltration estimation methods are therefore required to derive infiltration rates from fan pressurisation data.

Estimating infiltration rate from fan pressurisation tests is not a new idea (Warren and Webb, 1980b), and many empirical and theoretical air infiltration models have been developed: Warren and Webb (1980a), Shaw (1981), the ASHRAE Basic model (ASHRAE, 2013), which is based on the Lawrence Berkeley Laboratory (LBL) model (Sherman and Grimsrud, 1980), the ASHRAE Enhanced model (ASHRAE, 2013), which is based on the Alberta Infiltration Model (AIM-2) (Walker and Wilson 1990, 1998), the Kronvall and Persily (K-P) “divide-by-20" rule of thumb (Kronvall, 1978; Persily, 1983; Jones et al., 2016), and, in the UK, in the absence of a blower door test, the SAP Algorithm (BRE, 2012).

The most commonly used infiltration estimation methods in UK dwellings are the K-P "divide-by-20" method, which usually uses $q_{50}$ as the numerator in the UK, and SAP reduction method (Table 1). An alternative to an infiltration estimation method using blower door data or an algorithm is to select a reference infiltration value from a data table. In the UK, values listed in BREDEM (Anderson et al., 2002) may be used (BREDEM also has a fan pressurisation reduction method where $q_{50}$ is known), or the tabulated values in the CIBSE Guides (CIBSE, 2007, 2016). Choosing a reference value from a table is likely to be a very low accuracy estimate of infiltration and will not be considered in this study.

Although infiltration estimation methods were empirically validated during and soon after their development (e.g. Liddament and Allen, 1983), more recent evidence has questioned the ability of some infiltration estimation methods to accurately estimate infiltration rate, with calls for more research (Keig et al., 2016; Johnston and Stafford, 2017; Johnston et al., 2017; Johnston and Miles-Shenton, 2018; Kisilewicz et al., 2019; Vega Pasos et al. 2019, 2020; Mun et al., 2021).

The K-P "divide-by-20" method has drawn particular attention for being an inaccurate estimator (Keig et al., 2016; Johnston and Stafford, 2017; Vega Pasos et al. 2019, 2020) and so is deemed appropriate only for low precision estimations of air infiltration (Ramos et al., 2015) during the heating season (Jones et al., 2016). Despite this, it is claimed that the $\mathrm{K}-\mathrm{P}$ is the most used method (Patrascu et al., 2018).

More detailed methods exist for estimating air infiltration in dynamic thermal models such as air flow networks (AFN) and computational fluid dynamics (CFD), which are likely to provide more accurate estimates of infiltration rate. However, these methods require additional model input data and are time consuming to implement, so users of building energy simulation tools often use the aforementioned simplified infiltration estimation methods such as those based on empirical data (Table 1) (Djunaedy et al., 2003; Gowri et al., 2009). For modelling applications, there is always a trade-off between data requirements, ease of use, and computation time (Jones et al., 2015). And because "infiltration is often input to the model and forgotten about" (Roberts et al., 2019a), more guidance is needed to help modellers in their decision making when estimating infiltration. 
homes (Fox, 2008; Sharpe et al., 2015; Jones et al., 2017; Mavrogianni et al., 2017). However, recent guidance from the UK Government to occupants on how to reduce summertime overheating states that window openings should be reduced during very hot weather to prevent ingress of warmer outdoor air (MHCLG, 2021). This action could have implications for indoor air quality if background ventilation is insufficient. It is known that the transmission of the severe acute respiratory syndrome coronavirus 2 (SARS-CoV-2) virus, which causes coronavirus disease 2019 (COVID-19), occurs more readily in poorly ventilated indoor environments (Cevik et al., 2020; Meyerowitz et al., 2020; Greenhalgh et al., 2021; Jones et al., 2021; Qian et al., 2021). So reliable estimates of the infiltration rates during a summer heatwave when occupants are encouraged to close their windows is especially important.

Infiltration is expected to be lower in summer than winter because the variable drivers of infiltration, i.e. the wind speed and indoor-outdoor temperature difference (Labat et al., 2013), will also be lower (Binamu and Lindberg, 2002; Hong and Kim, 2016; Kisilewicz et al., 2019). Infiltration may also be lower in summer due to seasonal variation in building envelope air permeability which can be $20-40 \%$ lower in summer due to building materials expanding and contracting with seasonal changes in humidity (Warren and Webb, 1980b; Persily, 1983; Kim and Shaw, 1986; Bassett, 1992; Bracke et al., 2016). However, the estimates of infiltration rate may be least accurate in the summer season, with one relevant study showing that the difference between measured and estimated infiltration rates (Sherman Simplified model) were greater in summer and smaller in the winter (Kisilewicz et al., 2019). Because of growing concerns about summertime overheating, and to redress the wintertime focus of virtually all infiltration studies, this work measured infiltration rates in the summer.

The aim of this study is to examine whether infiltration estimation methods can accurately calculate summertime infiltration rates by comparing such estimates to infiltration rate measured using tracer gas. The key question is: "Are summertime infiltration rates produced by commonly used estimation methods reliable?".

\section{Methods}

\subsection{The test house}

A single, unoccupied, semi-detached test house, constructed in the 1930s, was used for all tests (Plate 1). Semi-detached houses are the most common dwelling type in England (25.3\%) and most were built between 1919 and 1944 (52\%) (MHCLG, 2018). Across England, there is surprisingly little variation between such 1930's semi-detached houses (Allen and Pinney, 1990).

The test house is located in a suburban residential area of Loughborough, UK $\left(52.771071^{\circ} \mathrm{N}\right.$, $\left.1.224264^{\circ} \mathrm{W}\right)$. The front of the house faces south-southeast $\left(160^{\circ}\right)$ towards a front garden and a road and the rear of the property faces north to a large back garden (Plate 2). The house has an exposed west-facing façade and adjoins to another semi-detached dwelling on the eastern side. The adjoining, identical dwelling was unoccupied during all testing, with no source of $\mathrm{CO}_{2}$ present to influence the tracer gas tests. There are neighbouring houses of similar roof height to the east and west (Plate 2).

The house has a floor area of $85.4 \mathrm{~m}^{2}$ (including both floors), an internally-measured envelope surface area of $226.0 \mathrm{~m}^{2}$ and a total volume of $209.2 \mathrm{~m}^{3}$. Floor to ceiling heights are $2.5 \mathrm{~m}$ on the ground floor and $2.4 \mathrm{~m}$ on the first floor (Figure 1). Scale drawings of the house and local site plans are publicly available (see Roberts et al., 2019b).

The house is constructed of uninsulated masonry-cavity walls, wet plastered with gypsum-based plaster on the internal walls, and a clay-tiled pitched roof. The ground floors comprise suspended timbers throughout (except the kitchen), which are ventilated by subfloor air bricks. In the kitchen the floor is solid concrete and unventilated. Carpet tiles, approximately $7 \mathrm{~mm}$ thick cover all floors apart from in the kitchen, upstairs bathroom, and

Estimating infiltration rates in summer 


\section{IJBPA \\ 41,1}

50

Plate 1.

The semi-detached test house where data were collected in

Loughborough, UK

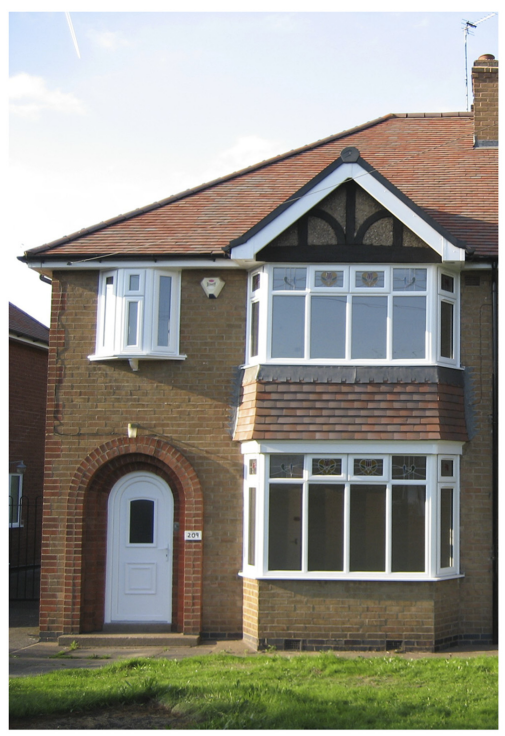

The test house from the front (south) side

(a)

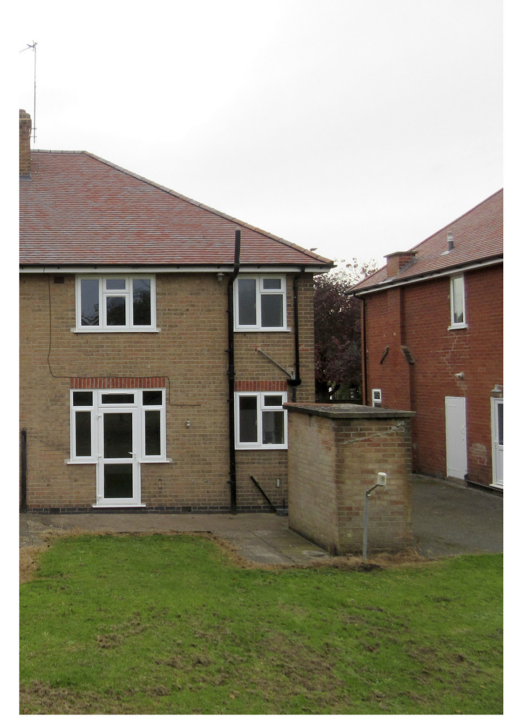

The test house from the rear (north) side

(b)

\section{Plate 2.}

Aerial photograph of the test house with neighbouring dwellings and wider site

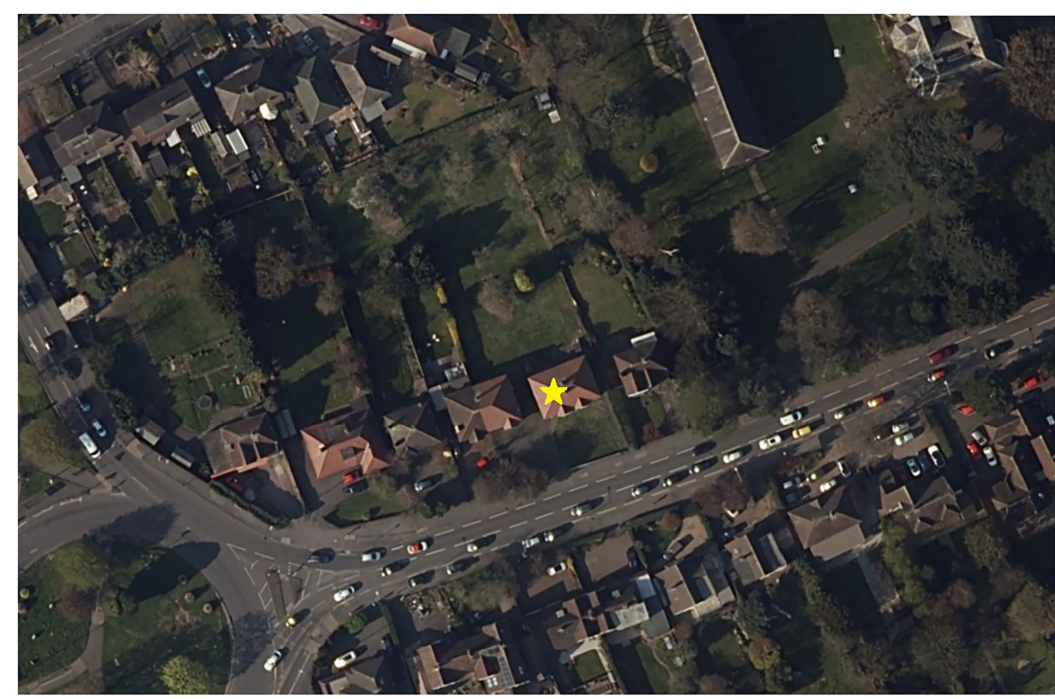

Note(s): North is top of photo. Gold star indicates the test house (Bing Maps, 2021)

WC, which are covered with linoleum. Estimated U-values for the dwelling envelope elements are listed in Roberts et al. (2018). The house has a heat transfer coefficient of $223 \mathrm{~W} / \mathrm{K}$, as measured by a co-heating test (Roberts et al., 2018). 


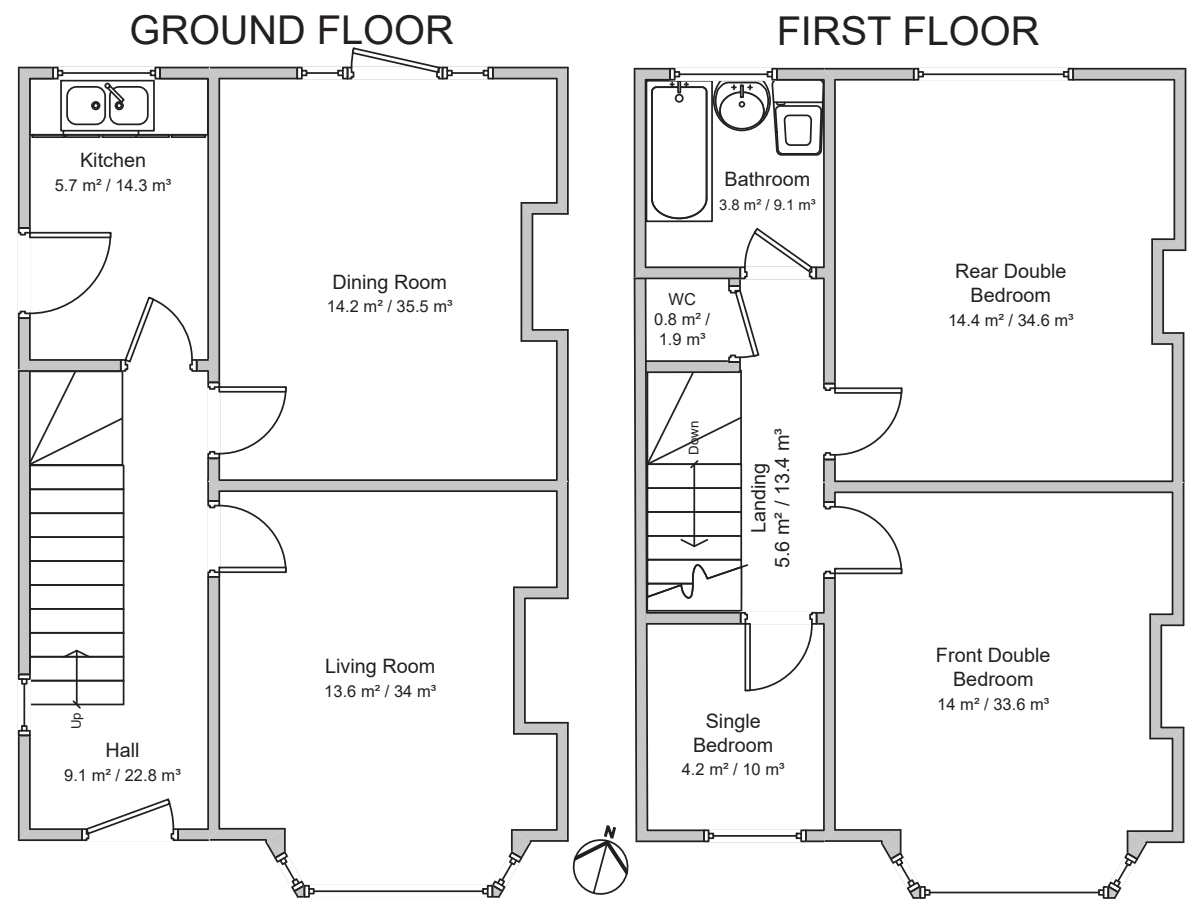

Note(s): The party wall is to the right hand side of the drawing, and adjoins to a house of identical geometry, with a mirrored floor plan (not shown)
Estimating infiltration rates in summer

Figure 1.

Floor plan of the test house

Since construction in the 1930s, the fireplaces in the living and dining room have been removed, bricked up, and plastered over. In 2016, the existing single-glazed, wooden-framed windows and external doors were replaced with double-glazed uPVC elements. At the same time, the roof tiles were replaced with like-for-like clay tiles and the bitumen roofing felt was replaced with a vapour-permeable membrane. The loft (attic) was insulated with $300 \mathrm{~mm}$ rockwool at the joists. The loft hatch was insulated, but not draught-proofed. A tile-hung exterior wall on the front bay between the living room and front double bedroom had new like-for-like clay tiles overlaid on a vapour-permeable membrane.

Some further modifications were made to the test house by the experimenters, prior to commencing the tests. The windows on the western façade were blocked with $50 \mathrm{~mm}$ foilbacked PIR insulation, cut precisely to size and inserted into the entire window reveal [2]. An airtight fit was assured using aluminium tape adhered to the insulation and wall surrounding the window, and the seal was verified using smoke sticks (Roberts et al., 2018). Wall vents were sealed using aluminium tape on the interior wall, but the exterior opening was left unsealed (Roberts et al., 2018). Fireplace vents were also sealed on the interior wall only. All sub-floor ventilation air bricks were left unsealed, with the size and locations available in Roberts et al. (2019b).

During the tracer gas and blower door tests, the houses were unheated and without mechanical ventilation (i.e. free-running). All internal doors $(0.71 \times 1.95 \mathrm{~m}$ opening) were propped open during all tests. Water traps in sinks, basins, baths, and toilets were filled with water. 
IJBPA 41,1

\section{2}

Summary of equipment used to measure indoor temperature and weather
Windows were always closed during testing, in order to examine the infiltration rate only. To measure additional background ventilation, in some tests, trickle vents were opened via the flap shutter. All trickle vents were open or closed simultaneously, although examination of different numbers of trickle vents has been explored in previous work (Roberts et al., 2017). In total the combined equivalent area of the 19 trickle vents was $25,000 \mathrm{~mm}^{2}$ (see Roberts et al. (2017) for trickle vent locations).

During all tests, the indoor dry bulb temperature was measured at one-minute intervals using a U-type thermistor hung from a tripod in the centre of every room at a height of $1.1 \mathrm{~m}$ from the floor and wired to a data logger (Table 2). All thermistors were calibrated prior to use in a water bath against a calibrated thermometer. A tubular foil-coated bubble wrap radiation shield was placed over every tripod to reduce incoming solar radiation contacting the thermistor. This radiation shield design allowed air to move freely around the thermistor, and care was taken to avoid the thermistor contacting the shield or the tripod.

Outdoor dry bulb temperature was measured at the location of the test house at oneminute intervals, using the same type of calibrated thermistor as used indoors. To protect from rain and solar radiation, the thermistor was encased in a naturally-aspirated radiation shield, which was placed in the garden on the north side of the house (Plate 1b). Wind speed and direction were measured at 10-min intervals at the University weather station $1 \mathrm{~km}$ from the test house (Table 2). There may be small differences between the weather conditions at the test houses and weather station due to the differing topography and sheltering or canyoning effects of surrounding buildings and trees.

\subsection{Measuring infiltration and background ventilation rate with tracer gas}

Fifteen whole house tracer gas tests were conducted to measure infiltration (trickle vents closed). Two tests in March 2017 (spring), and the remaining 13 in June-August 2018 (summer) (Table 3). Four further tests to measure the combined infiltration and background ventilation (trickle vents open) were completed in August 2018 (Table 3).

The UK summer of 2018 was the joint-hottest summer since records began in 1884 (McCarthy et al., 2019). For the two tests conducted during the spring, there was no heating in the test houses for some weeks prior and the temperature difference between indoors and outdoors remained small (Tables 3 and 4).

The maximum indoor temperature recorded during the tracer gas tests was $27.8^{\circ} \mathrm{C}$ and the maximum outdoor temperature during testing was $26.1{ }^{\circ} \mathrm{C}$. These maximum temperatures did not occur during the same test. The predominant wind direction was south-west $\left(218.4^{\circ}\right)$ during the infiltration tests (trickle vents closed) and west-southwest $\left(254.9^{\circ}\right)$ during the background ventilation tests (trickle vents open).

\begin{tabular}{|c|c|c|c|c|}
\hline Variable & Location & $\begin{array}{l}\text { Recording } \\
\text { interval }\end{array}$ & Device & Uncertainty \\
\hline $\begin{array}{l}\text { Dry bulb } \\
\text { temperature }\end{array}$ & All rooms and outside & $1 \mathrm{~min}$ & $\begin{array}{l}\text { Wired U-type } \\
\text { thermistor }^{\mathrm{a}}\end{array}$ & $\pm 0.3{ }^{\circ} \mathrm{C}$ \\
\hline Wind speed & $\begin{array}{l}\text { Campus weather } \\
\text { station }^{\mathrm{b}}\end{array}$ & $10 \mathrm{~min}$ & Combined anemometer & $\pm 0.1 \mathrm{~m} / \mathrm{s}$ \\
\hline Wind direction & $\begin{array}{l}\text { Campus weather } \\
\text { station }^{\text {b }}\end{array}$ & $10 \mathrm{~min}$ & Combined anemometer & $\pm 4^{\circ}$ \\
\hline
\end{tabular}




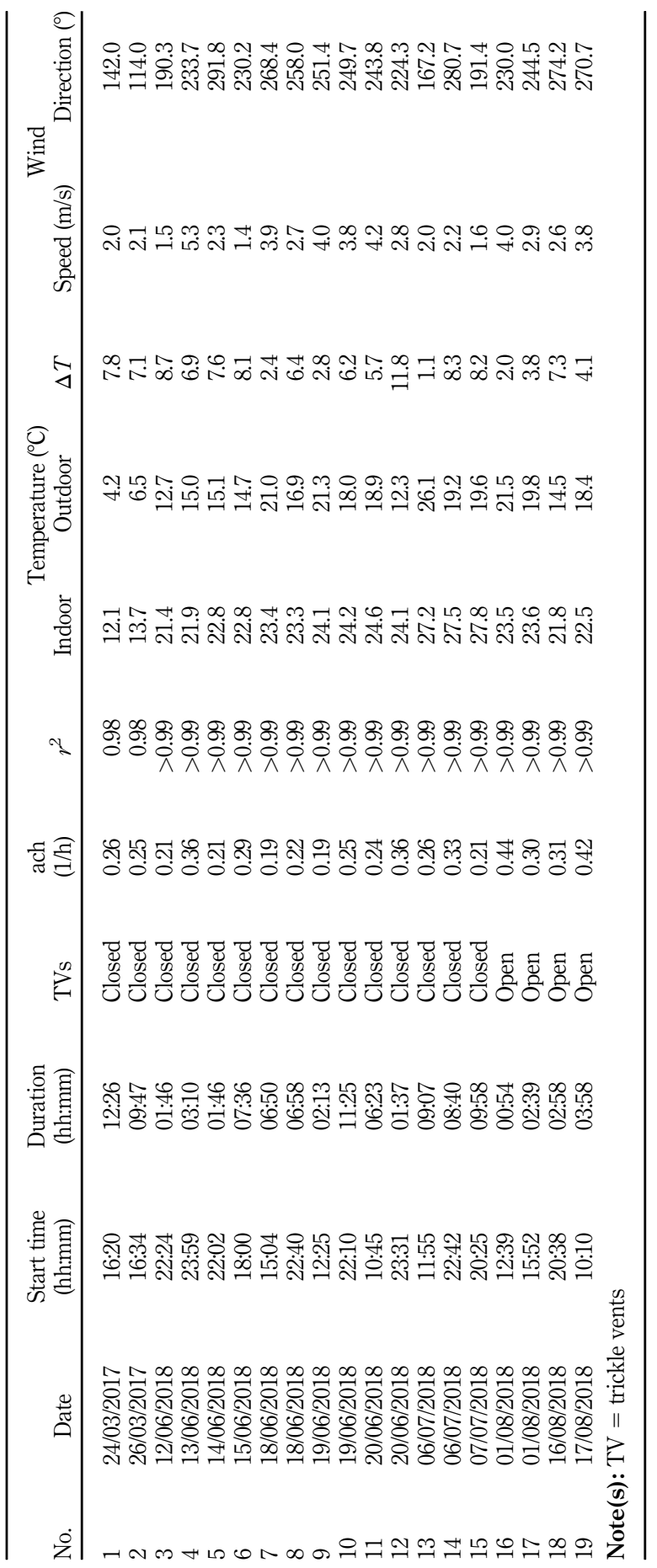

Estimating infiltration rates in summer

53

Table 3. Summary of all tracer gas tests 
IJBPA

41,1

\section{4}

Table 4.

Indoor-outdoor temperature $(\Delta T)$ and wind speed measured during the whole house Open tracer gas tests

The decay method, in compliance with the American Society for Testing and Materials (ASTM) standard (ASTM, 2000), was used for all tracer gas tests. Carbon dioxide $\left(\mathrm{CO}_{2}\right)$ was selected as the tracer gas. The tracer gas was injected from a $22 \mathrm{~kg}$ bottle of $\mathrm{CO}_{2}$ that was connected via PTFE tubing to a solenoid valve attached to a large floor-standing fan to immediately distribute the gas away from the dosing location. Pilot testing revealed that proper distribution of tracer gas throughout the house could be achieved with two injection points: one on the ground floor in the hall, and one on the first floor on the landing. Pilot testing using gas monitors at different heights showed that additional tracer gas mixing with room air was required, and so additional floor-standing fans were placed in every room and switched on during the tracer gas injection period to ensure proper mixing and to reduce stratification of the tracer gas. During this time, the operator monitored the $\mathrm{CO}_{2}$ concentration in each room to check for homogeneity and made adjustments to the placement of the injection fans as necessary. $\mathrm{CO}_{2}$ was injected in sufficient quantities to achieve a minimum concentration of 2,500 ppm evenly dispersed throughout the house. Once this tracer gas concentration was achieved, injection of gas was stopped and the fans were left running until homogeneous distribution of tracer gas was achieved in all rooms, the fans were then switched off. Data were not analysed during periods when fans were running.

Tracer gas concentration was measured using a multi-zone gas sampler [3] which took regular samples of air from the volumetric centre of six rooms, three on the ground floor and three on the first floor: the living room, dining room, hall, front double bedroom, rear double bedroom and landing. Air samples were pumped through nylon tubes, passing a dust filter, into the sampler and transferred via PTFE tubing (the tubing material selected to minimise absorption of air samples) to a gas analyser [4]. The gas analyser used photoacoustic infrared spectroscopy to analyse the air sample for $\mathrm{CO}_{2}$ concentration and compensated for water vapour (Lumasense Technologies Ltd, 2016). Sampling intervals were continuous, meaning that after a sample had been taken and analysed, the next was taken immediately. In practice the sampling interval was every three minutes, as it took around $30 \mathrm{~s}$ for each of the six sampling points. This measurement frequency is greater than the minimum recommended sampling frequency of $15 \mathrm{~min}$ (ASTM, 2000).

The combination of multi-zone sampler and gas analyser were chosen because they can monitor six separate zones (rooms) simultaneously and had a high degree of accuracy $( \pm 3 \%$ [5]). The ASTM standard recommends $\pm 5 \%$ accuracy (ASTM, 2000). The gas analyser was factory calibrated immediately prior to the experiments commencing and a nozzle calibration procedure was conducted by the operator prior to each individual test.

Data analysis began with a conformity check. To meet uniformity of concentration criterion stipulated in the ASTM standard (ASTM, 2000), the tracer gas concentration must differ between sampling points by less than $10 \%$ of the average concentration for the whole measurement zone. During the initial dosing and mixing phase, heterogeneity of concentration was expected, and analysis of the decay did not begin until homogeneity (within $10 \%$ of the mean) was established and the decay of tracer gas had begun. Tests were rejected from the analysis if the tracer gas concentration at one or more sampling points

\begin{tabular}{llrcrrr}
\hline Trickle vents & Weather & $n$ & Mean & SD & Min & Max \\
\hline Closed & $\Delta T(\mathrm{~K})$ & 15 & 6.6 & 2.7 & 1.1 & 11.8 \\
& Wind speed $(\mathrm{m} / \mathrm{s})$ & 15 & 2.8 & 1.2 & 1.4 & 5.3 \\
Open & $\Delta T(\mathrm{~K})$ & 4 & 4.3 & 2.2 & 2.0 & 7.3 \\
& Wind speed $(\mathrm{m} / \mathrm{s})$ & 4 & 3.3 & 0.7 & 2.6 & 4.0 \\
\hline
\end{tabular}


varied by more than $10 \%$ of the mean gas concentration of all sampling points at any time during the decay period.

The regression method was used to calculate the air change rate (ASTM, 2000). Air change rate $(1 / \mathrm{h})$ was derived from the slope of the regression line that represents $\ln \left(C_{N}\right)$ against time (Equation 1) (Roulet and Foradini, 2002). Being a natural constituent of air, $\mathrm{CO}_{2}$ decay will never reach zero. To account for this, ambient $\mathrm{CO}_{2}$ was measured as $430 \mathrm{ppm}$ [6], using the method outlined by Roulet and Foradini (2002).

$$
C_{N}=\frac{C(t)-C_{o}}{C(0)-C_{o}}
$$

where $C_{N}$ ppm $=$ the normalised concentration of $\mathrm{CO}_{2}$ at time $t, C(t)$ ppm $=$ indoor concentration of $\mathrm{CO}_{2}$ at time $t, C(0) \mathrm{ppm}=$ indoor concentration of $\mathrm{CO}_{2}$ at start of test, $C_{o}$ $\mathrm{ppm}=$ outdoor concentration of $\mathrm{CO}_{2}(430 \mathrm{ppm})$.

\subsection{Measuring air permeability with blower door tests}

Blower door tests were used to measure the whole house air flow rate of the test house after the method described by ASTM (2007) and ATTMA (2016) on days between January and March 2017. The air flow was induced and measured by a Model 3 Minneapolis Blower Door via depressurisation. The blower door test method uses the relationship between flow through the envelope and the pressure difference across it to quantify air permeability (Sherman, 1987). The test pressure difference of $50 \mathrm{~Pa}$ is selected due to being achievable by standard blower door devices in most houses, but high enough to make the test reasonably independent of weather influences (Chan et al., 2013). The fan speed was controlled and data were logged using the Tectite Express 3.6 software (TEC, 2021). The Tectite Express software took at least 10 measurements of air flow rate at a range of building pressure differences between approximately $90 \mathrm{~Pa}$ and $20 \mathrm{~Pa}$ at intervals of between 5 and $10 \mathrm{~Pa}$, which always included a measurement of air flow rate at a pressure difference above and below $50 \mathrm{~Pa}$. The whole house air flow $\left(\mathrm{m}^{3} / \mathrm{h}\right)$ measured by the blower door was normalised by dividing by either dwelling surface area or volume to calculate $q_{50}$ or $n_{50}$ respectively.

Two types of tests were conducted as per the ASTM standard (ASTM, 2007). With all trickle vents closed $(n=34)$, and with all trickle vents open $(n=8)$. The tests were conducted on 13 separate days in January, February, and March 2017 by the same operator. The blower door was placed into the same opening for all tests (dining room external door, Figure 1). This door was chosen after pilot testing alternative doors which were found to be inadequate due to shape (the front door was curved at the top and this made fitting a tight seal difficult, even after a section of wood was cut to fit) or because of obstructions from internal doors (kitchen external door) (Roberts et al., 2017).

The weather conditions during the blower door tests were recorded (Table 5). Most blower door tests were conducted under a south-westerly $\left(220.5^{\circ}\right)$ wind direction, as is the prevailing wind direction in the UK Although six of the 34 blower door tests with trickle vents closed were conducted under wind speeds which exceeded the $6 \mathrm{~m} / \mathrm{s}$ maximum recommended wind speed for testing $(6.2-6.8 \mathrm{~m} / \mathrm{s})$ (ATTMA, 2016), they did not deviate from the mean value by more than $0.1 \mathrm{~m}^{3} / \mathrm{h} \mathrm{m}^{2}$ and were retained in the dataset.

\begin{tabular}{|c|c|c|c|c|c|c|c|}
\hline Trickle vents & Weather & $n$ & Mean & $\mathrm{SD}$ & Min & Max & Table 5. \\
\hline \multirow[t]{2}{*}{ Closed } & $\Delta T(\mathrm{~K})$ & 34 & 7.6 & 3.4 & 0.9 & 13.0 & $\begin{array}{l}\text { Indoor-outdoor } \\
\text { temperature }(\Delta T) \text { and }\end{array}$ \\
\hline & Wind speed $(\mathrm{m} / \mathrm{s})$ & 34 & 3.8 & 1.8 & 1.1 & 6.8 & wind speed measured \\
\hline \multirow{2}{*}{ Open } & $\Delta T(\mathrm{~K})$ & 8 & 7.4 & 2.5 & 5.1 & 6.1 & during the whole house \\
\hline & Wind speed $(\mathrm{m} / \mathrm{s})$ & 8 & 1.6 & 0.4 & 1.1 & 1.4 & fan pressurisation tests \\
\hline
\end{tabular}

Estimating infiltration rates in summer 


\section{IJBPA 41,1}

\section{6}

Table 6

Assumed values for each of the ASHRAE Basic, ASHRAE Enhanced, K-P UK, K$\mathrm{P}$ US, LBL, and Modified K-P infiltration estimation methods

\subsection{Estimating air infiltration rate}

The infiltration rate measured by the tracer gas tests was estimated by 11 infiltration estimation methods, which are listed below. Only the cases with trickle vent closed (i.e. infiltration) were included in this analysis. This resulted in 15 tests for comparison. Where applicable the weather data measured at the time of each tracer gas test were used in each estimation method, taken as the mean value measured over the duration of each individual test (Tables 6 and 7). The weather conditions during the tracer gas tests were previously noted in Section 2.2.

The infiltration estimation methods required inputs from measured values as well as other assumptions (Tables 6 and 7). Where a method required data from a blower door test, this was taken as the mean value from the 34 tests with trickle vents closed.

Seasonal variation in building envelope air permeability could result in air leakage being lower in summer than winter (Warren and Webb, 1980b; Persily, 1983; Kim and Shaw, 1986; Bassett, 1992; Bracke et al., 2016). Thus, conducting the blower door tests at different times of the year to the tracer gas infiltration measurements could reduce the reliability of the infiltration estimation methods. To mitigate this, six of the blower door tests and two of the tracer gas tests were conducted in the same month (March 2017) (Table 3) with these results similar to the findings of the entire dataset. Furthermore, an additional fan pressurisation test was done in September 2017 (for quality assurance purposes and not included in the analyses), which yielded a result similar to that which had been recorded in the JanuaryMarch 2017 tests $\left(14.38 \mathrm{~m}^{3} / \mathrm{h} \mathrm{m}^{2} @ 50 \mathrm{~Pa}\right)$. Therefore, the influence of seasonal variation in

\begin{tabular}{|c|c|c|c|c|c|c|}
\hline Input & $\begin{array}{l}\text { ASHRAE } \\
\text { Basic }\end{array}$ & $\begin{array}{l}\text { ASHRAE } \\
\text { Enhanced }\end{array}$ & $\begin{array}{l}\text { K-P } \\
\text { UK }\end{array}$ & $\begin{array}{c}\mathrm{K}-\mathrm{P} \\
\mathrm{US} \\
\end{array}$ & LBL & Modified K-P \\
\hline Flow coefficient $(C)$ & - & 369.33 & - & - & - & - \\
\hline Flow exponent $(n)$ & - & 0.56 & - & - & - & - \\
\hline $\operatorname{ELA}\left(\mathrm{cm}^{2}\right)$ & 865.80 & - & - & - & 865.80 & - \\
\hline$q_{50}$ & - & - & 14.67 & - & - & - \\
\hline$n_{50}$ & - & - & - & 15.31 & - & 15.31 \\
\hline Storeys & 2 & 2 & - & - & 2 & - \\
\hline $\begin{array}{l}\text { Shelter class/shielding } \\
\text { parameter }\end{array}$ & 5 & 5 & - & - & 5 & - \\
\hline Flue & - & No flue & - & - & - & - \\
\hline Terrain coefficient & - & - & - & - & City & - \\
\hline $\begin{array}{l}\text { Chimneys, fans, flues, } \\
\text { PSVs }\end{array}$ & - & - & - & - & - & - \\
\hline Sheltered sides & - & - & - & - & - & - \\
\hline Structural infiltration & - & - & - & - & - & - \\
\hline Floor infiltration & - & Basement slab & - & - & - & - \\
\hline $\begin{array}{l}\text { Draught lobby } \\
\text { infiltration }\end{array}$ & - & - & - & - & - & - \\
\hline $\begin{array}{l}\text { Windows draught- } \\
\text { proofed }\end{array}$ & - & - & - & - & - & - \\
\hline Ventilation method & - & - & - & - & - & - \\
\hline Leakiness/crack factor & - & - & - & - & - & - \\
\hline Building volume & $209.2 \mathrm{~m}^{3}$ & $209.2 \mathrm{~m}^{3}$ & - & - & $209.2 \mathrm{~m}^{3}$ & - \\
\hline$\Delta T$ & $M$ & $M$ & - & - & $M$ & - \\
\hline Wind speed & $M$ & $M$ & - & - & $M$ & - \\
\hline
\end{tabular}

Note(s): The letter " $M$ " denotes that the mean measured value for $\Delta T$ or wind speed was used (unique for all 15 tests) 


\begin{tabular}{|c|c|c|c|c|c|c|}
\hline Input & $\begin{array}{l}\text { SAP Algorithm } \\
\text { (meas. wind) }\end{array}$ & $\begin{array}{l}\text { SAP Algorithm } \\
\text { (ref. wind) }\end{array}$ & $\begin{array}{l}\mathrm{SAP} q_{50} / 20 \\
\text { (meas. wind) }\end{array}$ & $\begin{array}{l}\mathrm{SAP} q_{50} / 20 \\
\text { (ref. wind) }\end{array}$ & $\begin{array}{l}\text { Sherman } \\
\text { Simplified }\end{array}$ & $\begin{array}{l}\text { Estimating } \\
\text { infiltration }\end{array}$ \\
\hline Flow coefficient $(C)$ & - & - & _- & _- & - & tes in \\
\hline Flow exponent $(n)$ & - & - & - & - & - & summer \\
\hline ELA & - & - & - & - & - & \\
\hline$q_{50}$ & - & - & 14.67 & 14.67 & - & \\
\hline$n_{50}$ & - & - & - & - & 15.31 & 57 \\
\hline Storeys & 2 & 2 & 2 & 2 & 2 & \\
\hline $\begin{array}{l}\text { Shelter class/ } \\
\text { shielding } \\
\text { parameter }\end{array}$ & - & - & - & - & Well shielded & \\
\hline Flue & - & - & - & - & - & \\
\hline Terrain coefficient & - & - & - & - & - & \\
\hline $\begin{array}{l}\text { Chimneys, fans, } \\
\text { flues, PSVs }\end{array}$ & 0 & 0 & 0 & 0 & - & \\
\hline Sheltered sides & 2 & 2 & 2 & 2 & - & \\
\hline $\begin{array}{l}\text { Structural } \\
\text { infiltration }\end{array}$ & $\begin{array}{l}\text { Masonry } \\
\text { construction }\end{array}$ & $\begin{array}{l}\text { Masonry } \\
\text { construction }\end{array}$ & - & - & - & \\
\hline Floor infiltration & $\begin{array}{l}\text { Unsealed } \\
\text { suspended timber }\end{array}$ & $\begin{array}{l}\text { Unsealed } \\
\text { suspended timber }\end{array}$ & - & - & - & \\
\hline $\begin{array}{l}\text { Draught lobby } \\
\text { infiltration }\end{array}$ & Not present & Not present & - & - & - & \\
\hline $\begin{array}{l}\text { Windows draught- } \\
\text { proofed }\end{array}$ & $100 \%$ & $100 \%$ & - & - & - & $\begin{array}{r}\text { Table } 7 . \\
\text { Assumed values for the }\end{array}$ \\
\hline Ventilation method & Nat vent & Nat vent & Nat vent & Nat vent & - & $\begin{array}{l}\text { SAP Algorithm } \\
\text {. }\end{array}$ \\
\hline $\begin{array}{l}\text { Leakiness/crack } \\
\text { factor }\end{array}$ & - & - & - & - & Normal & $\begin{array}{l}\text { (measured wind), SAP } \\
\text { Algorithm (reference }\end{array}$ \\
\hline Building volume & - & - & - & - & - & $\begin{array}{r}\text { wind), SAP } q_{50} / 20 \\
\text { (measured wind), SAP }\end{array}$ \\
\hline$\Delta T$ & - & - & - & - & $M$ & $\begin{array}{l}\text { (measured wind), SAP } \\
q_{50} / 20 \text { (reference wind), }\end{array}$ \\
\hline Wind speed & $M$ & $R$ & $M$ & $R$ & $M$ & and Sherman \\
\hline \multicolumn{6}{|c|}{$\begin{array}{l}\text { Note(s): The letter " } M \text { " denotes that the mean measured value for } \Delta T \text { or wind speed was used (unique for all } \\
15 \text { tests). " } R \text { " denotes that a reference value for wind speed was used (subject to the month of the test) }\end{array}$} & $\begin{array}{r}\text { Simplified infiltration } \\
\text { estimation methods }\end{array}$ \\
\hline
\end{tabular}

building envelope air permeability on the reliability of the infiltration estimation methods is deemed to be negligible in this study.

The equations for each method are listed in the referenced sources and repeated with full description of the specific inputs for this house in Roberts (2020).

(1) ASHRAE Basic model (ASHRAE, 2013), called the Effective Leakage Area model in EnergyPlus (DoE, 2020).

(2) ASHRAE Enhanced model (ASHRAE, 2013), called the Flow Coefficient model in EnergyPlus (DoE, 2020).

(3) K-P (Kronvall-Persily) UK (Kronvall, 1978; Persily, 1983). Which uses a divisor of 20 to reduce the blower door data. The method is applied differently in the United States and the United Kingdom: in the K-P UK model, air permeability $\left(q_{50}\right)$ is used (Poza-Casado et al., 2020).

(4) K-P US (Kronvall, 1978; Persily, 1983). In the K-P US model, airtightness $\left(n_{50}\right)$ is used.

(5) Lawrence Berkeley Laboratory (LBL) model (Sherman and Grimsrud, 1980; Sherman and Modera, 1986). 
IJBPA

41,1

\section{8}

(6) Modified divisor K-P model $n_{50} / 30$ (Dubrul, 1988; Liddament, 1996). As the K-P US model, but the leakage-infiltration ratio is 30 , as suggested for low-rise buildings by Dubrul (1988) and Liddament (1996).

(7) SAP Algorithm (measured wind) (BRE, 2012). Measured wind, using the average wind speed measured during the test interval.

(8) SAP Algorithm (reference wind) (BRE, 2012). Reference wind values for wind speed for the corresponding month as supplied in SAP.

(9) SAP $q_{50} / 20$ (measured wind) (BRE, 2012).

(10) SAP $q_{50} / 20$ (reference wind) (BRE, 2012).

(11) Sherman Simplified model (Sherman, 1987). This method usually requires annual average wind speed and indoor-outdoor temperature difference, but in this analysis the average during each of the tracer gas test intervals was used.

Standard metrics were derived to enable the difference between the measured and estimated infiltration (i.e. the error $E$ ) to be quantified (Table 8). For each of the standard metrics, $E_{t}=P_{t}-M_{t}$, where $P_{t}$ is the estimated infiltration rate for a particular test $t, M_{t}$ is the measured infiltration rate for the matching test $t$, and $n$ is the total number of infiltration rates being compared.

\section{Results}

The tracer gas test results are provided to establish the measured infiltration rate; the blower door test results are given, as these inform many of the infiltration estimation methods; the measured and estimated infiltration rates are compared.

\subsection{Infiltration rate and background ventilation rate measured by tracer gas}

The mean air change rate values for infiltration (trickle vents closed) and background ventilation (trickle vents open) as measured by tracer gas were calculated (Table 9) from the tracer gas decays (Figure 2). The mean air change rate was lower when trickle vents were closed than open, and the difference in means was statistically significant $(p<0.05)$.

\subsection{Air permeability measured by blower door tests}

The mean air permeability $\left(q_{50}\right)$, as measured via blower door tests (Table 10 ), was higher (i.e. the dwelling envelope was more leaky) than the current UK standard for new dwellings of

Table 8.

Standard metrics for representation of measurementestimation error (difference between)

\begin{tabular}{llll}
\hline Error statistic & Acronym & Units & Formula \\
\hline Mean bias error & MBE & ach & $\frac{\sum_{t=1}^{n}\left(E_{t}\right)}{n}$ \\
Mean absolute error & MAE & ach & $\frac{\sum_{t=1}^{n}\left|E_{t}\right|}{n}$ \\
Maximum error & Max E & ach & $\operatorname{Max} E_{t}$ \\
Minimum error & Min E & ach & $\operatorname{Min} E_{t}$ \\
Root mean square error & RMSE & ach & $\sqrt{\frac{\sum_{t=1}^{n}\left(E_{t}\right)^{2}}{n}}$ \\
Normalised mean bias error & NMBE & $\%$ & $\frac{M B E}{\bar{M}} \times 100$ \\
Coefficient of variation of root mean square error & CVRMSE & $\%$ & $\frac{R M S E}{\bar{M}} \times 100$ \\
\hline
\end{tabular}


$10 \mathrm{~m}^{3} / \mathrm{h} \mathrm{m}^{2}$ (HM Government, 2010), though comparable to dwellings of similar age (Stephen, 2000). Opening all trickle vents resulted in a statistically significant increase in mean air permeability $(\phi<0.05)$.

It was decided that a single mean value for $q_{50}$ and $n_{50}$ could be used in the infiltration estimation methods that required it. This was on the basis that the sample means, as calculated from 34 blower door tests with trickle vents closed had a very small standard error which indicated that the population mean would fall between $\pm 0.09 \mathrm{~m}^{3} / \mathrm{h} \mathrm{m}^{2} @ 50 \mathrm{~Pa}$ (and 0.09 ach @ 50 Pa for $n_{50}$ ) in $95 \%$ of cases (Table 10). Thus, a single central mean value for $q_{50}$ and $n_{50}$ was used in all the infiltration estimation methods that required it.

Some infiltration estimation methods required parameters from the blower door tests instead of $q_{50}$ or $n_{50}$, namely flow coefficient $C$, flow exponent $n$ and effective leakage area (ELA). The value for each of these input parameters was taken as the mean from 34 blower door tests with trickle vents closed (Tables 6 and 7 ).

\begin{tabular}{lcccccccccc}
\hline & \multicolumn{1}{c}{ Closed } & \multicolumn{1}{c}{ Trickle vents } \\
& $n$ & Mean & SD & Min & Max & $n$ & Mean & $\begin{array}{l}\text { Open } \\
\text { SD }\end{array}$ & Min & Max \\
\hline Air change rate $(1 / \mathrm{h})$ & 15 & 0.25 & 0.06 & 0.19 & 0.36 & 4 & 0.36 & 0.07 & 0.30 & 0.44
\end{tabular}

Estimating infiltration rates in summer

Table 9.

Infiltration (trickle vents closed) and background ventilation (trickle vents open) test results measured via tracer gas in air changes per hour $(1 / h)$

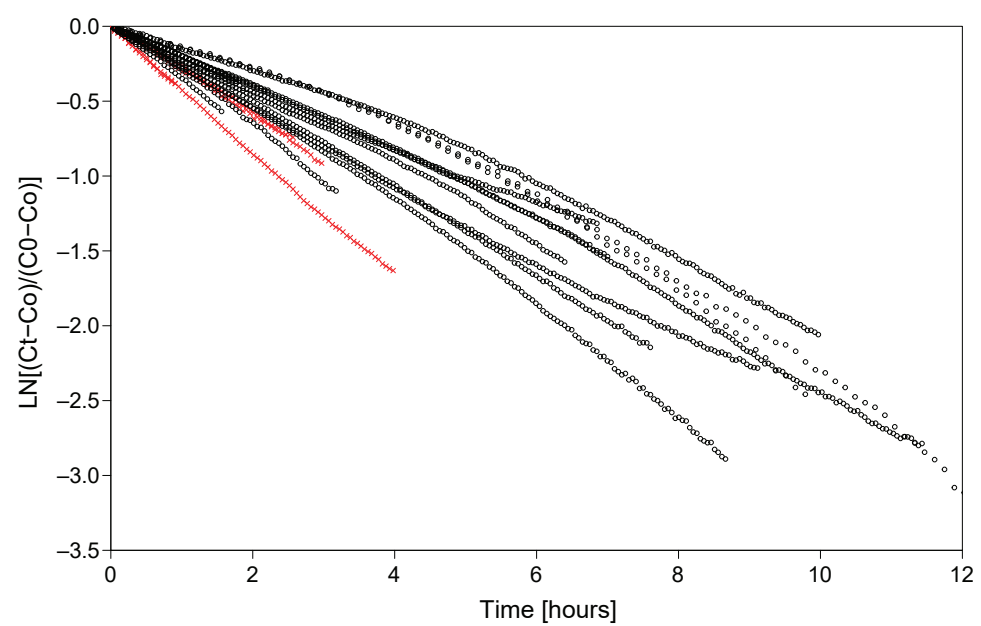

Note(s): Black circles are the 15 inltration (trickle vents closed) decay tests, red crosses are the four background ventilation (trickle vents open) decay tests

\begin{tabular}{|c|c|c|c|c|c|c|c|c|c|c|}
\hline & & & & & Trick & n & & & & \\
\hline & $n$ & Mean & $\begin{array}{l}\text { Closed } \\
\text { SD }\end{array}$ & Min & $\operatorname{Max}$ & $n$ & Mean & $\begin{array}{l}\text { Open } \\
\text { SD }\end{array}$ & Min & $\operatorname{Max}$ \\
\hline $\begin{array}{l}q_{50}\left(\mathrm{~m}^{3} / \mathrm{h} \mathrm{m}^{2} @ 50 \mathrm{~Pa}\right) \\
n_{50}(1 / \mathrm{h} @ 50 \mathrm{~Pa})\end{array}$ & $\begin{array}{l}34 \\
34\end{array}$ & $\begin{array}{l}14.67 \\
15.31\end{array}$ & $\begin{array}{l}0.26 \\
0.28\end{array}$ & $\begin{array}{l}14.29 \\
14.91\end{array}$ & $\begin{array}{l}15.41 \\
16.08\end{array}$ & 8 & $\begin{array}{l}16.52 \\
17.24\end{array}$ & $\begin{array}{l}0.28 \\
0.29\end{array}$ & $\begin{array}{l}16.09 \\
16.79\end{array}$ & 7. \\
\hline
\end{tabular}

Figure 2.

$\log$ normal $\mathrm{CO}_{2}$ concentration decays over time

Table 10.

Whole house air permeability $\left(q_{50}\right)$ and airtightness $\left(n_{50}\right)$ measured via fan pressurisation, with trickle vents closed and open 
IJBPA

41,1

Qualitative analysis of air leakage paths using neutrally-buoyant smoke and infrared thermography showed the main routes for infiltration to be: at plumbing and electrical service envelope penetrations; around some plug sockets; at the floor/wall interface and around skirting boards; at the loft hatch; and under window ledges. Windows were generally well sealed, but there was some leakage around trickle vents, even in their closed position. This is reflected in earlier work in this house which found the air permeability to be $2 \%$ lower with trickle vents in their closed position and sealed with tape compared to being closed but unsealed (Roberts et al., 2017).

\subsection{Comparing measured and estimated infiltration rates}

All infiltration estimation methods predicted a higher mean infiltration rate than was measured by tracer gas (Table 11 and Figure 3 ). The mean infiltration rates estimated by each of the methods varied from 64 to $208 \%$ higher than the mean measured infiltration rate.

The ASHRAE Enhanced method estimated the mean infiltration rate that was closest to the mean measured value, but was still significantly $(\phi<0.001)$ higher than measured (Tables 11 and 12, and Figure 3). The K-P US model mean was furthest from the mean measured value [7]. Dividing $n_{50}$ by 30 (K-P modified divisor) was the second most accurate method, but a divisor of 58 would be required to perfectly predict the mean infiltration rate measured in this study (under summer weather conditions). Thus, none of the infiltration estimation methods could accurately predict the mean infiltration rate in this house, under the summer weather conditions experienced.

Whilst all the mean estimated infiltration rates were significantly different from the mean measured value, some of the individual data points were close to the corresponding measured value, and in some cases lower than the measured infiltration rate (Table 12 and Figure 4). The ASHRAE Basic, ASHRAE Enhanced, LBL model, and the Sherman Simplified method all have minimum errors of $\leq 0.10$ ach (positive and negative, i.e. greater and less than measured). Equally, some single data points are much higher than the measured value (see maximum error in Table 12 and Figure 3). Therefore, the methods trialled cannot be relied upon to make consistently reliable estimations of the summertime infiltration rate.

The estimation methods which accounted for the weather conditions (and indoor temperature) were generally more reliable estimators of infiltration than those which did not (e.g. K-P US and K-P UK methods) (Figure 3). Using a locally measured value for wind speed generally improved the predictions compared to a reference value for wind speed (e.g. compare SAP measured wind to SAP reference wind).

However, the use of a variable input: locally-measured wind speed and the indoor-outdoor temperature difference, meant that the range of infiltration estimation was, unsurprisingly, higher than in the estimation methods which did not account for wind (or used a reference value) and, more interestingly, greater than the range in measured values (Figure 3 and Table 11). Yet, despite the greater range in estimated infiltration rates when locally measured wind speeds were used, the mean values were still generally closer to the measured value than if no wind speed data were used.

The variation in the 15 measured infiltration rates may be attributed to the varying weather conditions in each of the 15 tests (Roberts, 2020). The slope of the regression line for each estimation method is indicative of each method's response to those weather conditions (Figure 4). The ASHRAE Enhanced, LBL and Sherman Simplified methods all appear to respond correctly to the change in weather conditions, with the slope angle of the lines close to 1, i.e. the line of quality, albeit significantly above (Figure 4). The other estimation methods using measured wind speed are somewhat reliable predictors of the change in infiltration rate. The two SAP methods with reference wind do not display the correct rate of change, neither do the K-P UK, US, or $n_{50} / 30$ methods, due to having no weather data input (Figure 4). 


\section{IJBPA \\ 41,1}

\section{2}

Figure 3.

A comparison of the measured infiltration rates (tracer gas) and the estimated infiltration rates from each of the methods

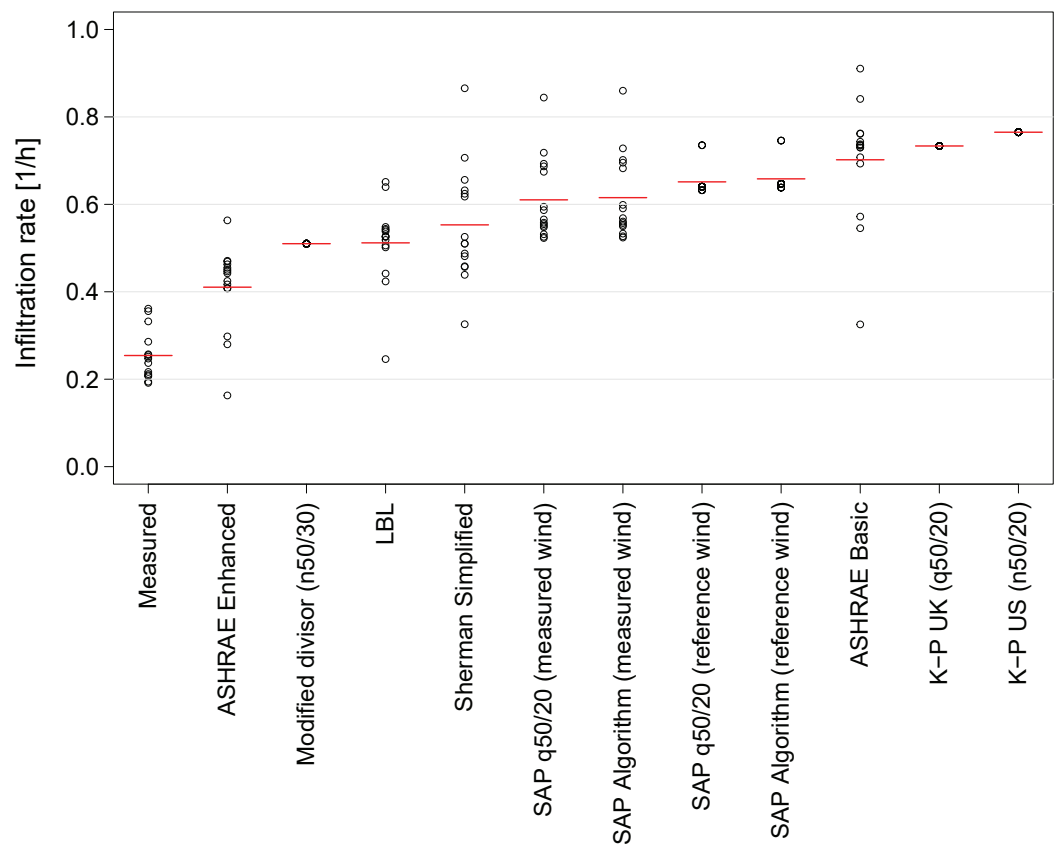

Note(s): Each data point represents one of the 15 measured or estimated infiltration rates. The mean value for each of the methods is indicated by the red horizontal bars. Arranged in ascending order from the lowest mean infiltration rate value

\section{Discussion}

This paper is, to the authors' knowledge, the only time that eleven infiltration estimation methods have been compared to measured infiltration in a UK dwelling. Also notable is the summertime focus of this research, where most previous studies have examined wintertime infiltration. This research has shown that none of the infiltration estimation methods tested were reliable predictors of the mean infiltration rate under the summertime conditions in which they were examined. The mean infiltration rates estimated by the 11 methods were between 64 and $208 \%$ higher than the mean measured infiltration rate.

The commonly used K-P UK and K-P US (“divide-by-20") methods should not be used to estimate summertime infiltration in typical UK homes. This finding is supported by previous studies (Keig et al., 2016; Jones et al., 2016; Johnston and Stafford, 2017; Cardoso et al., 2020; Vega Pasos et al., 2020) and, crucially, this study adds evidence with a summertime focus.

For the house tested in this work, and under these weather conditions, a divisor of 58 for $q_{50}$ and $n_{50}$ was required to perfectly estimate the mean measured infiltration rate. This is even higher than the divisor of between 37 and 39 suggested elsewhere (Vega Pasos et al. 2019, 2020) [8]. It is possible that seeking a single divisor for estimating infiltration from blower door tests is futile for anything other than very low resolution, low reliability estimates of annual average infiltration rate: there are complex geometrical considerations and infiltration is highly dynamic and weather-dependent (Jones et al., 2015).

Generally, the methods which were sensitive to the varying nature of infiltration rate were the more reliable estimators of the mean infiltration rate. The methods which accounted for the wind speed, indoor-outdoor temperature differences, and perhaps other information 

estimated) statistics for each of the infiltration 


\section{IJBPA \\ 41,1}

\section{4}

Figure 4.

Measured infiltration rate plotted against estimated infiltration rate

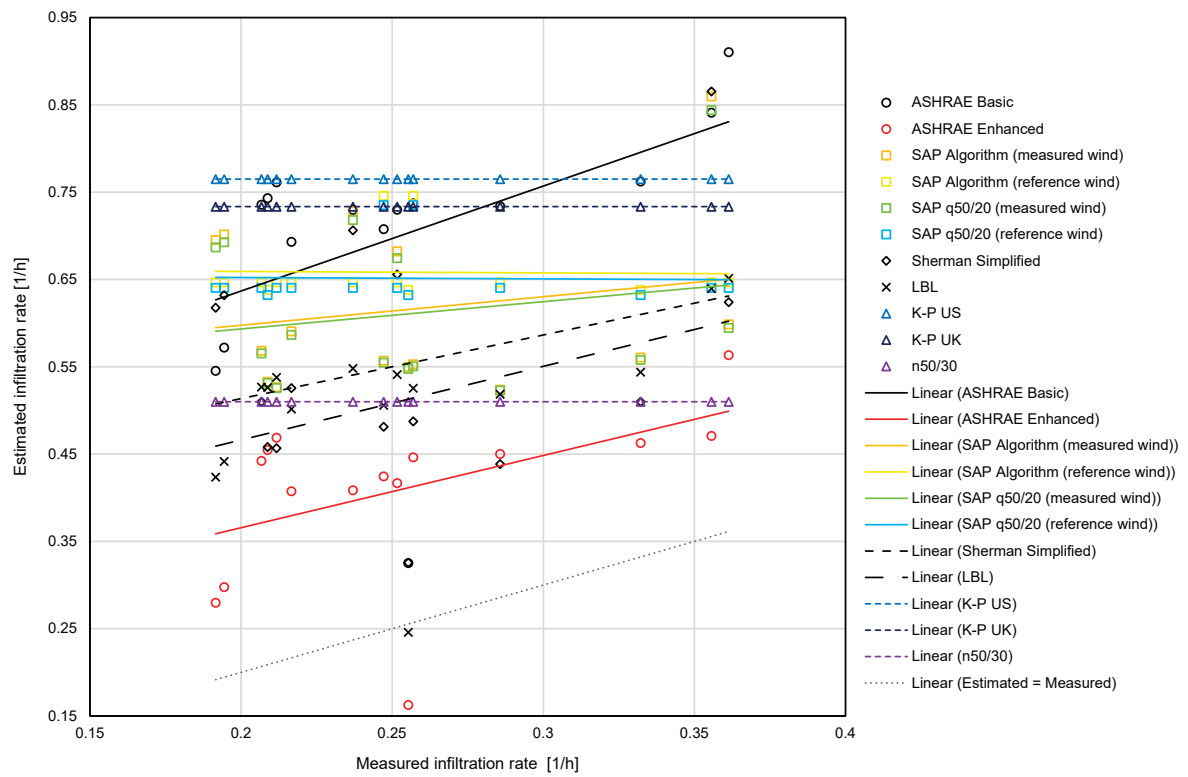

Note(s): Each data point represents one of the 15 tracer gas tests and the equivalent estimation method prediction

about the building and wider site were the ASHRAE Basic, ASHRAE Enhanced, LBL, SAP Algorithm, SAP q50/20 and Sherman Simplified methods. Infiltration is more reliably estimated when local weather data are used rather than reference values, e.g. compare SAP Algorithm measured wind to reference wind. Although it is not always possible or practical to obtain local weather data, there are clear benefits to doing so if more reliable estimates of infiltration rate are required.

These findings have implications for the reliable prediction of overheating risk and cooling demand. Overheating risk may be higher than models predict, as ventilative cooling is not as high as assumed by modellers. This could mean that appropriate and necessary passive overheating mitigation strategies are not implemented at the design stage. This could lead to overheating in new homes and the subsequent uptake of energy intensive airconditioning.

Looking to the future, cooling demand is likely to increase in UK homes (Gupta et al., 2015), and reliable estimations of infiltration will be needed to accurately predict cooling load. Windows are likely to be closed when mechanical cooling is operating, and so infiltration rather than ventilation through purpose-provided openings will become the dominant air exchange path. Reliable estimation of infiltration is therefore imperative to design cooling systems of appropriate size.

These findings also indicate that indoor air quality may be worse than expected, due to the air change rate being lower than current estimates. The test house used in this research was at risk of poor indoor air quality when the windows were closed in summer, and even when the trickle vents were open. A new UK dwelling of equivalent size to the test house requires a background ventilation rate of $25.62 \mathrm{l} / \mathrm{s}(0.44 \mathrm{ach})$, which is $22.5 \%$ higher than the $20.92 \mathrm{1} / \mathrm{s}$ $(0.36 \mathrm{ach})$ that was measured (HM Government, 2010). In contrast, had the infiltration estimation methods been used to assess the indoor air quality, all but the ASHRAE Enhanced 
method would have (incorrectly) assumed indoor air quality to be satisfactory in the house, even without the trickle vents open. Therefore, households may be at risk of exposure to poor indoor air quality in summer when the windows are closed on hot days to prevent ingress of warmer outdoor air. This has implications for health and wellbeing. Ultimately, this work suggests that trickle vents cannot be relied on for the provision of satisfactory indoor air quality in summer. Further measurement in a wider range of homes is urgently needed to address this.

The ASHRAE Enhanced method (ASHRAE, 2013), which is called the Flow Coefficient model in Energy Plus (DoE, 2020)) shows the greatest potential for adaptation and adjustment to summertime conditions, based on these results. The ASHRAE Enhanced method estimated a mean infiltration rate that was both closest to the measure infiltration rate and the gradient of the regression line (Figure 4) was similar to the gradient of the line of equality. Thus, it appears that this method was reliably sensitive to the changes in infiltration rate. Therefore, the ASHRAE Enhanced method shows the greatest promise and further investigation and refinement of this approach for estimation of infiltration rate in summer is recommended.

\section{Conclusion}

Due to the time, expense and intrusive nature of measuring infiltration directly using tracer gas in homes, infiltration rate is usually estimated, and often using information collected in a blower door test. This paper adds to the body of evidence that the commonly used methods of estimating infiltration rate are inaccurate in UK homes, and so infiltration is not reliably estimated. Importantly, where previous work has tended to focus on wintertime infiltration, this study demonstrates the magnitude of infiltration estimation error in the summer season. Infiltration in summer is important when predicting summertime overheating risk, calculating mechanical cooling loads, and assessing indoor air quality on hot days when occupants are encouraged to close windows to prevent this ingress of warmer outdoor air.

Infiltration rate (trickle vents closed) was measured by 15 whole house tracer gas tests in a typical semi-detached English dwelling built in the 1930s. Thirty-four blower door tests were carried out under the same conditions to measure the dwelling air permeability. Four tracer gas and eight blower door tests were also conducted with trickle vents open to measure background ventilation rate. The majority of tests took place during the joint-hottest summer on record in the UK. The measured infiltration rate was compared to that estimated by eleven infiltration estimation methods. The key conclusions are the following:

(1) None of the eleven infiltration estimation methods trialled was a reliable estimator of the mean infiltration rate measured in the test house.

(2) If the commonly used K-P "divide-by-20" rule of thumb is used to estimate infiltration, the divisor for $q_{50}$ and $n_{50}$ should be replaced by 58 . However, attempts to define a single value to reduce blower door data $\left(q_{50}\right.$ or $\left.n_{50}\right)$ to infiltration rate is futile when considering the highly dynamic and weather-dependent nature of infiltration.

(3) Infiltration estimation methods which account for wind speed (especially when locally measured), indoor-outdoor temperature differences, and perhaps other information about the building and wider site are recommended to achieve more reliable estimates of infiltration, but still differences between the measured and estimated infiltration remained.

(4) The ASHRAE Enhanced infiltration estimation method was closest to the mean measured infiltration rate and demonstrated a similar rate of increase in estimated infiltration in line with the measured value. Thus, this method holds the greatest
Estimating infiltration rates in summer 
IJBPA

41,1

potential for adjustment and adaptation to be more suitable for estimating infiltration in typical UK homes during summer.

(5) Incorrectly estimating infiltration could lead to incorrect assumptions regarding indoor air quality, overheating risk and cooling loads. In this test house, indoor air quality was measured as unsatisfactory even with trickle vents open, despite all but one infiltration estimation method (ASHRAE Enhanced) predicting a sufficient air change rate even with trickle vents closed.

Further research is required to adjust the existing infiltration estimation methods which show the greatest potential, i.e. the ASHRAE Enhanced method, for more reliable estimation of infiltration rate under summer weather conditions. This work has presented evidence from a typical UK home, but future work should also consider new build homes, which are likely to be built to higher standards of airtightness. This will allow for more reliable infiltration estimation methods to be developed and thus for proper ventilation strategies to be designed both to ameliorate summertime overheating and ensure provision of satisfactory indoor air quality.

\section{Notes}

1. Figures for the global energy demand and $\mathrm{CO}_{2}$ emission due to heat production are limited. The quoted values include heat consumption for space heating and water heating in buildings, for cooking and for operating industrial processes.

2. This endeavour was primarily to reduce solar gains entering via glazing on the western façade but is noted here as it is likely to very slightly reduce the infiltration rate compared to a similar house of comparable age and construction.

3. Lumasense Innova 1303 Sampler and Doser (Lumasense Technologies Ltd. 2016).

4. Lumasense Innova 1412i Gas Monitor.

5. Lumasense Technologies Ltd. (2016).

6. $\mathrm{ppm}=$ parts per million.

7. The values for $q_{50}$ and $n_{50}$ were similar because the building surface area and volume are similar. Thus, the K-P US and K-P UK methods yielded similar, but not identical, results. The values would be different in a house where the surface area to volume ratio is not close to 1 .

8. In dwellings of non-standard construction, caravans, a divisor for $n 50$ of 40 has been suggested (Miles-Shenton et al., 2015).

\section{References}

Alfano, F.d., Dell'Isola, M., Ficco, G. and Tassini, F. (2012), "Experimental analysis of air tightness in Mediterranean buildings using the fan pressurization method", Building and Environment, Vol. 53, pp. 16-25.

Allen, E. and Pinney, A. (1990), Standard Dwellings for Modelling: Details of Dimensions, Construction and Occupancy Schedules, Building Environmental Performance Analysis Club Watford, Watford.

Anderson, B., Chapman, P., Cutland, N., Dickson, C., Doran, S., Henderson, G., Henderson, J., Iles, P., Kosmina, L. and Shorrock, L. (2002), BREDEM-8: Model Description 2001 Update, Building Research Establishment.

Ashdown, M.M., Crawley, J., Biddulph, P., Wingfield, J., Lowe, R. and Elwell, C.A. (2020), "Characterising the airtightness of dwellings", International Journal of Building Pathology and Adaptation, Vol. 38 No. 1, pp. 89-106.

ASHRAE (2013), 2013 ASHRAE Handbook - Fundamentals, SI Edition, American Society of Heating, Refrigerating and Air-Conditioning Engineers, Atlanta. 
ASTM (2000), Standard Test Method for Determining Air Change in a Single Zone by Means of a Tracer Gas Dilution. E741-11, Technical report, American Society for Testing Materials, West Conshohocken, PA.

ASTM (2007), Standard Test Methods for Determining Airtightness of Buildings Using an Orifice Blower Door. E1827-11, Technical report, American Society for Testing Materials, West Conshohocken, PA.

ATTMA (2016), Technical Standard L1: Measuring Air Permeability in the Envelopes of Dwellings, The Air Tightness Testing \& Measurement Association, Buckinghamshire.

Banfill, P.F., Simpson, S., Gillott, M.C. and White, J. (2011), The Potential for Energy Saving in Existing Solid Wall Dwellings through Mechanical Ventilation and Heat Recovery, European Council for an Energy Efficient Economy, Belambra Presqu'ile de Giens, pp. 6-031, summer study.

Banfill, P., Simpson, S., Haines, V. and Mallaband, B. (2012), "Energy-led retrofitting of solid wall dwellings: technical and user perspectives on airtightness", Structural Survey, Vol. 30, pp. 267-279.

Bassett, M. (1992), "House airtightness variation with age", 10th International PLEA Conference 'Passive and low energy architecture'. 19-22 August, 1992. Auckland, New Zealand.

Beizaee, A., Allinson, D., Lomas, K.J., Foda, E. and Loveday, D.L. (2015), "Measuring the potential of zonal space heating controls to reduce energy use in UK homes: the case of un-furbished 1930s dwellings", Energy and Buildings, Vol. 92 No. 0, pp. 29-44.

Binamu, A. and Lindberg, R. (2002), "Estimation of air infiltration of buildings based on the degree of air tightness and climatic data", Proceedings of Indoor Air 2002, pp. 382-387.

Bing Maps (2021), "Bing Maps”, available at: https://www.bing.com/maps (accessed 1 March 2021).

Bracke, W., Laverge, J., Bossche, N.V.D. and Janssens, A. (2016), "Durability and measurement uncertainty of airtightness in extremely airtight dwellings", International Journal of Ventilation, Vol. 14 No. 4, pp. 383-394.

BRE (2012), The Government's Standard Assessment Procedure for Energy Rating of Dwellings, Published by BRE on behalf of DECC, Garston, Watford.

Cardoso, V.E., Pereira, P.F., Ramos, N.M. and Almeida, R.M. (2020), "The impacts of air leakage paths and airtightness levels on air change rates", Buildings, Vol. 10 No. 3, p. 55.

Cevik, M., Kuppalli, K., Kindrachuk, J. and Peiris, M. (2020), "Virology, transmission, and pathogenesis of SARS-CoV-2", BMJ, p. 371.

Chan, W.R., Nazaroff, W.W., Price, P.N., Sohn, M.D. and Gadgil, A.J. (2005), "Analyzing a database of residential air leakage in the United States”, Atmospheric Environment, Vol. 39 No. 19, pp. 3445-3455.

Chan, W.R., Joh, J. and Sherman, M.H. (2013), "Analysis of air leakage measurements of US houses", Energy and Buildings, Vol. 66, pp. 616-625.

CIBSE (2007), Environmental Design: CIBSE Guide A, 7th ed., The Chartered Institution of Building Services Engineers, London, No. 2.

CIBSE (2016), CIBSE Guide B, The Chartered Institution of Building Services Engineers, London.

Collier, U. (2018), "Renewable heat policies: delivering clean heat solutions for the energy transition", IEA Insight Series, IEA Publications. IEA/OECD, Paris.

Crawley, J., Wingfield, J. and Elwell, C. (2019), "The relationship between airtightness and ventilation in new UK dwellings", Building Services Engineering Research and Technology, Vol. 40 No. 3, pp. 274-289.

Crawley, J., Biddulph, P., Wingfield, J., Ashdown, M., Lowe, R. and Elwell, C. (2020a), "Inferring the asbuilt air permeability of new UK dwellings", International Journal of Building Pathology and Adaptation, Vol. 38 No. 1, pp. 3-19.

Crawley, J., Wang, X., Ogunin, S., Vorushlyo, I. and Taneja, S. (2020b), IVUGER Report: Domestic Air Conditioning in 2050, Technical report, UK Energy Research Centre (UKERC), London.

Estimating infiltration rates in summer 
IJBPA

41,1

Djunaedy, E., Hensen, J. and Loomans, M. (2003), "Development of a guideline for selecting a simulation tool for airflow prediction", Eighth International IBPSA Conference, Eindhovan, Netherlands.

DoE (2020), Energyplus: Engineering Reference, U.S. Department of Energy, EnergyPlus Version 9.4.0 Documentation, Berkeley, CA.

Dubrul, C. (1988), Inhabitants Behaviour with Regard to Ventilation, IEA Annex VIII Report, Bracknell, Berkshire.

Echarri-Iribarren, V., Sotos-Solano, C., Espinosa-Fernández, A. and Prado-Govea, R. (2019), "The Passivhaus standard in the Spanish Mediterranean: evaluation of a house's thermal behaviour of enclosures and airtightness", Sustainability, Vol. 11 No. 13, p. 3732.

Fernández-Agüera, J., Domínguez-Amarillo, S., Sendra, J.J. and Suárez, R. (2016), “An approach to modelling envelope airtightness in multi-family social housing in Mediterranean Europe based on the situation in Spain", Energy and Buildings, Vol. 128, pp. 236-253.

Fox, J. (2008), A Study of Occupant Controlled Ventilation within UK Dwellings, $\mathrm{PhD}$ thesis, University College London, London.

Gowri, K., Winiarski, D.W. and Jarnagin, R.E. (2009), Infiltration Modeling Guidelines for Commercial Building Energy Analysis, Technical report, Pacific Northwest National Lab (PNNL), Richland, WA (United States).

Greenhalgh, T., Jimenez, J.L., Prather, K.A., Tufekci, Z., Fisman, D. and Schooley, R. (2021), “Ten scientific reasons in support of airborne transmission of SARS-CoV-2", The Lancet, Vol. 397 No. 10285 , pp. 1603-1605.

Gupta, R., Gregg, M. and Williams, K. (2015), "Cooling the UK housing stock post-2050s”, Building Services Engineering Research and Technology, Vol. 36 No. 2, pp. 196-220.

Hacker, J.N., De Saulles, T.P., Minson, A.J. and Holmes, M.J. (2008), "Embodied and operational carbon dioxide emissions from housing: a case study on the effects of thermal mass and climate change", Energy and Buildings, Vol. 40 No. 3, pp. 375-384.

HM Government (2010), The Building Regulations 2000. Part F1 Means of Ventilation, London.

HMG (2016), Carbon Footprint of Heat Generation, POSTnote 523, Parliamentary Office of Science and Technology, London.

Hong, G. and Kim, B.S. (2016), "Field measurements of infiltration rate in high rise residential buildings using the constant concentration method", Building and Environment, Vol. 97, pp. 48-54.

Jack, R., Loveday, D., Allinson, D. and Lomas, K. (2016), "Quantifying the effect of window opening on the measured heat loss of a test house", Sustainable Ecological Engineering Design, Springer, pp. 183-196.

Jack, R., Loveday, D., Allinson, D. and Lomas, K. (2018), "First evidence for the reliability of building co-heating tests", Building Research and Information, Vol. 46 No. 4, pp. 383-401.

Ji, Y. and Duanmu, L. (2017), "Airtightness field tests of residential buildings in Dalian, China”, Building and Environment, Vol. 119, pp. 20-30.

Johnston, D. and Miles-Shenton, D. (2018), "The airtightness and air leakage characteristics of new UK holiday homes", Building Services Engineering Research and Technology, Vol. 39 No. 3, pp. 343-361.

Johnston, D. and Stafford, A. (2017), "Estimating the background ventilation rates in new-build UK dwellings - is n50/20 appropriate?", Indoor and Built Environment, Vol. 26 No. 4, pp. 502-513.

Johnston, D., Farmer, D. and Miles-Shenton, D. (2017), "Quantifying the aggregate thermal performance of UK holiday homes", Building Services Engineering Research and Technology, Vol. 38 No. 2, pp. 209-225.

Jones, B., Das, P., Chalabi, Z., Davies, M., Hamilton, I., Lowe, R., Mavrogianni, A., Robinson, D. and Taylor, J. (2015), "Assessing uncertainty in housing stock infiltration rates and associated heat loss: english and UK case studies", Building and Environment, Vol. 92, pp. 644-656. 
Jones, B., Persily, A. and Sherman, M. (2016), "The origin and application of leakage-infiltration ratios", 2016 Conference Proceeding by ASHRAE and AIVC IAQ.

Jones, R.V., Fuertes, A., Gregori, E. and Giretti, A. (2017), "Stochastic behavioural models of occupants' main bedroom window operation for UK residential buildings", Building and Environment, Vol. 118, pp. 144-158.

Jones, B., Sharpe, P., Iddon, C., Hathway, E.A., Noakes, C.J. and Fitzgerald, S. (2021), "Modelling uncertainty in the relative risk of exposure to the SARS-CoV-2 virus by airborne aerosol transmission in well mixed indoor air", Building and Environment, Vol. 191, p. 107617.

Kalamees, T. (2007), "Air tightness and air leakages of new lightweight single-family detached houses in Estonia”, Building and Environment, Vol. 42 No. 6, pp. 2369-2377.

Keig, P., Hyde, T. and McGill, G. (2016), "A comparison of the estimated natural ventilation rates of four solid wall houses with the measured ventilation rates and the implications for low-energy retrofits", Indoor and Built Environment, Vol. 25 No. 1, pp. 169-179.

Kim, A.K. and Shaw, C.Y. (1986), "Seasonal variation in airtightness of two detached houses", in Measured Air Leakage of Buildings, ASTM International, Philadelphia.

Kisilewicz, T., Nowak-Dzieszko, K. and Rojewska-Warchał, M. (2019), "Transition from n50 to actual air exchange dependent on climatic conditions", MATEC Web of Conferences, Vol. 282, EDP Sciences, p. 02101.

Kronvall, J. (1978), "Testing of houses for air leakage using a pressure method", ASHRAE Transactions, Vol. 84 No. 1, pp. 72-79.

Labat, M., Woloszyn, M., Garnier, G. and Roux, J.J. (2013), “Assessment of the air change rate of airtight buildings under natural conditions using the tracer gas technique. comparison with numerical modelling", Building and Environment, Vol. 60, pp. 37-44.

Li, M., Allinson, D. and Lomas, K. (2019a), "Estimation of building heat transfer coefficients from inuse data", International Journal of Building Pathology and Adaptation, Vol. 38, pp. 38-50.

Li, X., Taylor, J. and Symonds, P. (2019b), "Indoor overheating and mitigation of converted lofts in London, UK", Building Services Engineering Research and Technology, Vol. 40 No. 4, pp. 409-425.

Liddament, M.W. (1996), A Guide to Energy Efficient Ventilation. Air Infiltration and Ventilation Centre Coventry, Coventry.

Liddament, M.W. and Allen, C. (1983), The Validation and Comparison of Mathematical Models of Air Infiltration, Air Infiltration Centre, Coventry.

Lomas, K.J. and Porritt, S.M. (2017), "Overheating in buildings: lessons from research", Building Research and Information, Vol. 45 Nos 1-2, pp. 1-18.

Love, J., Wingfield, J., Smith, A., Biddulph, P., Oreszczyn, T., Lowe, R. and Elwell, C. (2017), "Hitting the target and missing the point': analysis of air permeability data for new UK dwellings and what it reveals about the testing procedure”, Energy and Buildings, Vol. 155, pp. 88-97.

Lumasense Technologies Ltd (2016), Innova Multi-Gas Monitoring Instruments - 1412i. Innova 1412i Datasheet-EN 2016, Ballerup.

Mavrogianni, A., Wilkinson, P., Davies, M., Biddulph, P. and Oikonomou, E. (2012), "Building characteristics as determinants of propensity to high indoor summer temperatures in London dwellings", Building and Environment, Vol. 55, pp. 117-130.

Mavrogianni, A., Davies, M., Taylor, J., Chalabi, Z., Biddulph, P., Oikonomou, E., Das, P. and Jones, B. (2014), "The impact of occupancy patterns, occupant-controlled ventilation and shading on indoor overheating risk in domestic environments", Building and Environment, Vol. 78, pp. 183-198.

Mavrogianni, A., Pathan, A., Oikonomou, E., Biddulph, P., Symonds, P. and Davies, M. (2017), "Inhabitant actions and summer overheating risk in London dwellings", Building Research and Information, Vol. 45 Nos 1-2, pp. 119-142.
Estimating infiltration rates in summer 
IJBPA

41,1

McCarthy, M., Christidis, N., Dunstone, N., Fereday, D., Kay, G., Klein-Tank, A., Lowe, J., Petch, J., Scaife, A. and Stott, P. (2019), "Drivers of the UK summer heatwave of 2018", Weather, Vol. 74 No. 11 , pp. 390-396.

Mélois, A.B., Moujalled, B., Guyot, G. and Leprince, V. (2019), "Improving building envelope knowledge from analysis of 219,000 certified on-site air leakage measurements in France", Building and Environment, Vol. 159, p. 106145.

Meyerowitz, E.A., Richterman, A., Gandhi, R.T. and Sax, P.E. (2020), "Transmission of SARS-CoV-2: a review of viral, host, and environmental factors", Annals of Internal Medicine, Vol. 174 No. 1, pp. 69-79.

MHCLG (2018), English Housing Survey, 2016: Housing Stock Data, Ministry of Housing, Communities and Local Government, London, doi: 10.5255/UKDA-SN-8350-1 (accessed 10 January 2019).

MHCLG (2019), Research into Overheating in New Homes: Phase 1 Report, Ministry of Housing, Communities Local Government, London.

MHCLG (2021), Home User Guide Template, Ministry of Housing, Communities and Local Government, London, available at: https://assets.publishing.service.gov.uk/government/uploads/system/ uploads/attachment_data/file/953432/Home_User_Guide_Template.pdf (accessed 19 January 2021).

Miles-Shenton, D., Farmer, D. and Johnston, D. (2015), Investigation into the in Situ Thermal Performance of 2 Static Caravans - Assessing the Change in Heat Loss Behaviour Due to Thermally Superior Replacement Windows, Project Report, Leeds Sustainability Institute, Leeds.

Mun, J., Lee, J. and Kim, M. (2021), "Estimation of infiltration rate (ach natural) using blower door test and simulation", Energies, Vol. 14 No. 4, p. 912.

Oikonomou, E., Davies, M., Mavrogianni, A., Biddulph, P., Wilkinson, P. and Kolokotroni, M. (2012), "Modelling the relative importance of the urban heat island and the thermal quality of dwellings for overheating in London”, Building and Environment, Vol. 57, pp. 223-238.

Palin, S., McIntyre, D. and Edwards, R. (1996), "Ventilation for humidity control: measurements in a ventilation test house", Building Services Engineering Research and Technology, Vol. 17 No. 2, pp. 79-84.

Pan, W. (2010), "Relationships between air-tightness and its influencing factors of post-2006 new-build dwellings in the UK", Building and Environment, Vol. 45 No. 11, pp. 2387-2399.

Parker, J., Farmer, D., Johnston, D., Fletcher, M., Thomas, F., Gorse, C. and Stenlund, S. (2019), "Measuring and modelling retrofit fabric performance in solid wall conjoined dwellings", Energy and Buildings, Vol. 185, pp. 49-65.

Patrascu, M., Baracu, T., Badescu, V., Birsan, M.-V., Teodosiu, C., Degeratu, M., Avram, E.R., Udrea, M., Calancea, L. and Mesteru, C. (2018), "Modeling air leakage in buildings caused by the cyclic variation of the atmospheric pressure", Building Services Engineering Research and Technology, Vol. 39 No. 4, pp. 430-462.

Persily, A.K. (1983), Understanding Air Infiltration in Homes, PhD thesis, Princeton University, New Jersey.

Porritt, S., Shao, L., Cropper, P. and Goodier, C. (2011), “Adapting dwellings for heat waves”, Sustainable Cities and Society, Vol. 1 No. 2, pp. 81-90.

Porritt, S.M., Cropper, P.C., Shao, L. and Goodier, C.I. (2012), "Ranking of interventions to reduce dwelling overheating during heat waves", Energy and Buildings, Vol. 55, pp. 16-27.

Poza-Casado, I., Cardoso, V.E., Almeida, R.M., Meiss, A., Ramos, N.M. and Padilla-Marcos, M.Á. (2020), "Residential buildings airtightness frameworks: a review on the main databases and setups in Europe and North America”, Building and Environment, p. 107221.

Qian, H., Miao, T., Liu, L., Zheng, X., Luo, D. and Li, Y. (2021), "Indoor transmission of SARS-CoV-2", Indoor Air, Vol. 31 No. 3, pp. 639-645. 
Ramos, N.M., Almeida, R.M., Curado, A., Pereira, P.F., Manuel, S. and Maia, J. (2015), “Airtightness and ventilation in a mild climate country rehabilitated social housing buildings-what users want and what they get", Building and Environment, Vol. 92, pp. 97-110.

Roberts, B.M. (2020), Ventilation and Shading to Reduce Overheating in UK Homes: An Evaluation Using Matched Pair Test Houses with Synthetic Occupants, PhD thesis, Loughborough University, Loughborough.

Roberts, B.M., Allinson, D., Lomas, K.J. and Porritt, S. (2017), "The effect of refurbishment and trickle vents on airtightness: the case of a 1930s semi-detached house", 38th AIVC Conference, Nottingham, UK.

Roberts, B.M., Allinson, D. and Lomas, K.J. (2018), "A matched pair of test houses with synthetic occupants to investigate summertime overheating", Journal of Sustainable Design and Applied Research, Vol. 6 No. 1, p. 4.

Roberts, B.M., Allinson, D., Diamond, S., Abel, B., Das Bhaumik, C., Khatami, N. and Lomas, K.J. (2019a), "Predictions of summertime overheating: comparison of dynamic thermal models and measurements in synthetically occupied test houses", Building Services Engineering Research and Technology, Vol. 40 No. 4, pp. 512-552.

Roberts, B.M., Allinson, D. and Lomas, K. (2019b), Prediction of Overheating in Synthetically Occupied UK Homes: Dataset for Validating Dynamic Thermal Models of Buildings, Loughborough University Figshare Dataset, Loughborough, doi: 10.17028/rd.lboro.8094575 (accessed 30 July 2019).

Rodrigues, L., Tubelo, R., Vega Pasos, A., Gonçalves, J.C.S., Wood, C. and Gillott, M. (2020), "Quantifying airtightness in Brazilian residential buildings with focus on its contribution to thermal comfort", Building Research and Information, pp. 1-22.

Roulet, C.-A. and Foradini, F. (2002), "Simple and cheap air change rate measurement using $\mathrm{CO}_{2}$ concentration decays", International Journal of Ventilation, Vol. 1 No. 1, pp. 39-44.

Sfakianaki, A., Pavlou, K., Santamouris, M., Livada, I., Assimakopoulos, M.-N., Mantas, P. and Christakopoulos, A. (2008), "Air tightness measurements of residential houses in Athens, Greece”, Building and Environment, Vol. 43 No. 4, pp. 398-405.

Sharpe, T., Farren, P., Howieson, S., Tuohy, P. and McQuillan, J. (2015), "Occupant interactions and effectiveness of natural ventilation strategies in contemporary new housing in Scotland, UK", International Journal of Environmental Research and Public Health, Vol. 12 No. 7, pp. 8480-8497.

Shaw, C.Y. (1981), "Correlation between air infiltration and air tightness for houses in a developed residential area”, ASHRAE Transactions (United States), Vol. 87 Nos CONF-810657-

Sherman, M.H. (1987), "Estimation of infiltration from leakage and climate indicators", Energy and Buildings, Vol. 10 No. 1, pp. 81-86.

Sherman, M.H. and Dickerhoff, D.J. (1998), "Air-tightness of US dwellings", Transactions-American Society of Heating Refrigerating and Air Conditioning Engineers, Vol. 104, pp. 1359-1367.

Sherman, M. and Grimsrud, D. (1980), "Infiltration-pressurization correlation: simplified physical modeling", Conference of the American Society of Heating, Refrigeration and Air Conditioning Engineers, Denver, CO, June 22-26, 1980.

Sherman, M.H. and Modera, M.P. (1986), "Comparison of measured and predicted infiltration using the LBL infiltration model”, Measured Air Leakage of Buildings, ASTM International, Philadelphia.

Simson, R., Kurnitski, J. and Kuusk, K. (2017), "Experimental validation of simulation and measurement-based overheating assessment approaches for residential buildings", Architectural Science Review, Vol. 60 No. 3, pp. 192-204.

Sinnott, D. (2016), "Dwelling airtightness: a socio-technical evaluation in an Irish context", Building and Environment, Vol. 95, pp. 264-271.

Sinnott, D. and Dyer, M. (2012), “Air-tightness field data for dwellings in Ireland”, Building and Environment, Vol. 51, pp. 269-275.

Stephen, R. (2000), Airtightness in UK Dwellings, BRE, Garston, Watford. 
IJBPA 41,1

Taylor, J., Davies, M., Mavrogianni, A., Chalabi, Z., Biddulph, P., Oikonomou, E., Das, P. and Jones, B. (2014a), "The relative importance of input weather data for indoor overheating risk assessment in dwellings", Building and Environment, Vol. 76, pp. 81-91.

Taylor, J., Shrubsole, C., Davies, M., Biddulph, P., Das, P., Hamilton, I., Vardoulakis, S., Mavrogianni, A., Jones, B. and Oikonomou, E. (2014b), "The modifying effect of the building envelope on population exposure to PM 2.5 from outdoor sources", Indoor Air, Vol. 24 No. 6, pp. 639-651.

Taylor, J., Wilkinson, P., Davies, M., Armstrong, B., Chalabi, Z., Mavrogianni, A., Symonds, P., Oikonomou, E. and Bohnenstengel, S.I. (2015), "Mapping the effects of urban heat island, housing, and age on excess heat-related mortality in London", Urban Climate, Vol. 14, pp. 517-528.

Taylor, J., Davies, M., Mavrogianni, A., Shrubsole, C., Hamilton, I., Das, P., Jones, B., Oikonomou, E. and Biddulph, P. (2016), "Mapping indoor overheating and air pollution risk modification across Great Britain: a modelling study", Building and Environment, Vol. 99, pp. 1-12.

Taylor, J., Wilkinson, P., Picetti, R., Symonds, P., Heaviside, C., Macintyre, H.L., Davies, M., Mavrogianni, A. and Hutchinson, E. (2018), "Comparison of built environment adaptations to heat exposure and mortality during hot weather, West Midlands region, UK", Environment International, Vol. 111, pp. 287-294.

TEC (2021), Tectite Express 3.6, The Energy Conservatory, Minneapolis, MN, available at: https:// energyconservatory.com/downloads/tectite-express (accessed 1 March 2021).

Vega Pasos, A., Zheng, X., Gillott, M. and Wood, C. (2019), "Comparison between infiltration rate predictions using the divide-by-20 rule of thumb and real measurements", 40th AIVC Conference, Ghent, Belgium, October 2019.

Vega Pasos, A., Zheng, X., Smith, L. and Wood, C. (2020), "Estimation of the infiltration rate of UK homes with the divide-by-20 rule and its comparison with site measurements", Building and Environment, Vol. 185, p. 107275.

Vinha, J., Manelius, E., Korpi, M., Salminen, K., Kurnitski, J., Kiviste, M. and Laukkarinen, A. (2015), "Airtightness of residential buildings in Finland", Building and Environment, Vol. 93, pp. 128-140.

Walker, I. and Wilson, D. (1990), AIM-2 the Alberta Air Infiltration Model, The University of Alberta, Department of Mechanical Engineering, Edmonton, Alberta, Report 71.

Walker, I.S. and Wilson, D.J. (1998), "Field validation of algebraic equations for stack and wind driven air infiltration calculations", HVAC\&R Research, Vol. 4 No. 2, pp. 119-139.

Warren, P. and Webb, B. (1980a), "The relationship between tracer gas and pressurization techniques in dwellings", Proceedings of First Air Infiltration Center Conference, pp. 245-276.

Warren, P. and Webb, B. (1980b), "Ventilation measurements in housing", Proceedings of the CIBS Symposium on Natural Ventilation by Design, pp. 22-34.

\section{Corresponding author}

Ben M. Roberts can be contacted at: B.M.Roberts@lboro.ac.uk

For instructions on how to order reprints of this article, please visit our website:

www.emeraldgrouppublishing.com/licensing/reprints.htm

Or contact us for further details: permissions@emeraldinsight.com 